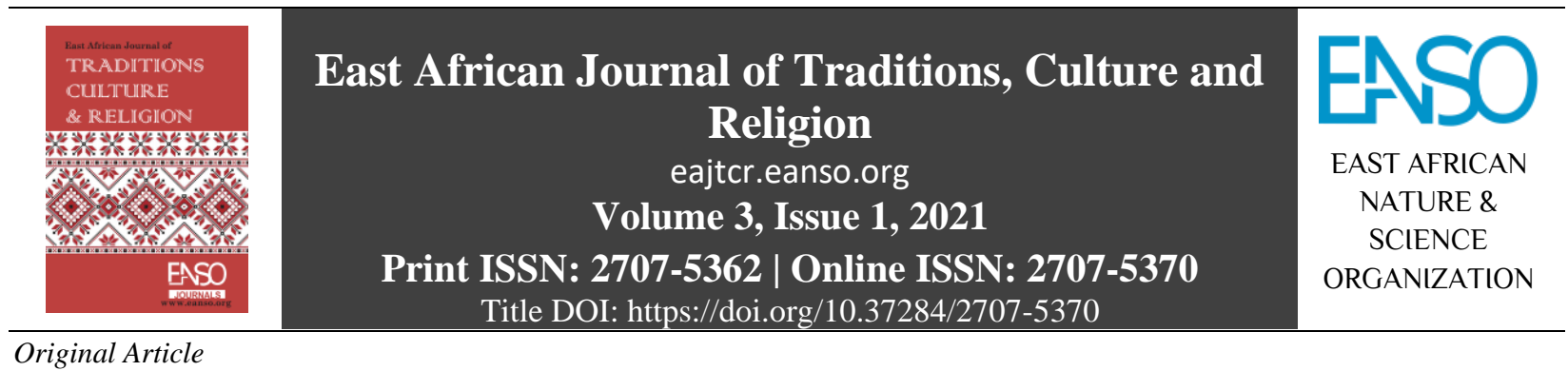

\title{
The Unethical Nature of Abuse of Childless Women in African Traditional Thought/Practice
}

\author{
Mark Omorovie Ikeke ${ }^{1^{*}}$ \\ ${ }^{1}$ Department of Religious Studies and Philosophy, Delta State University PMB 1, Abraka, Nigeria. \\ *Author for Correspondence Email: Ikeke7@yahoo.com. \\ * ORCID: https://orcid.org/0000-0001-9115-378X.
}

Article DOI: https://doi.org/10.37284/eajtcr.3.1.299

\section{Date Published:}

18 March 2021

Keywords:

Confronting Marriages, African Traditional,

Challenge of Marriage

Childlessness,

Cultural Practices,

Unethical Treatments.

\section{ABSTRACT}

One of the major challenges confronting marriages and families in African from the past to the present is the issue of barrenness or childlessness. Childlessness was often blamed on the woman, even though at times it may arise from the medical conditions of a man. African traditional culture had great value for children and childless marriage was seen as cursed and the woman in particular was even labelled a "man" or a witch. The woman is often verbally abused, and physical violence was meted on her. The marriage is often made unbearable and uncomfortable for the woman by the man or the in-laws of the woman. In some exceptional cases, the man and his relatives were understanding and coped with the situation or the man was allowed to marry another woman, while bearing with the childless woman. In order to cope with the challenge of childlessness women even encouraged their husbands to marry another woman (women). This paper written from critical philosophical analysis and hermeneutics argues that this abuse of childless women is unethical/immoral. The paper will draw upon instances from both written and oral literature to bring light on this belief and practice. No woman or man gives children. Even though a woman may have conditions that may impede the birth of children, it is rare to see a woman causing her own childlessness. These cultural practices that still influence the attitude and (mal) treatment of women need to be denounced and abrogated. The paper finds and concludes there is a need to end these unethical treatments of childless women.

\section{APA CITATION}

Ikeke, M. O. (2021). The Unethical Nature of Abuse of Childless Women in African Traditional Thought/Practice. East African Journal of Traditions, Culture and Religion, 3(1), 12-22. https://doi.org/10.37284/eajtcr.3.1.299 


\section{CHICAGO CITATION}

Ikeke, Mark. Omorovie. 2021. "The Unethical Nature of Abuse of Childless Women in African Traditional Thought/Practice". East African Journal of Traditions, Culture and Religion 3 (1), 12-22. https://doi.org/10.37284/eajtcr.3.1.299.

\section{HARVARD CITATION}

Ikeke, M. O. (2021) "The Unethical Nature of Abuse of Childless Women in African Traditional Thought/Practice", East African Journal of Traditions, Culture and Religion, 3(1), pp. 12-22. doi: 10.37284/eajtcr 3.1.299.

\section{IEEE CITATION}

M. O. Ikeke, "The Unethical Nature of Abuse of Childless Women in African Traditional Thought/Practice”, EAJTCR, vol. 3, no. 1, pp. 12-22 Mar. 2021.

\section{MLA CITATION}

Ikeke, Mark. Omorovie. "The Unethical Nature of Abuse of Childless Women in African Traditional Thought/Practice." East African Journal of Traditions, Culture and Religion, Vol. 3, no. 1, Mar. 2021, pp. 12-22, doi:10.37284/eajtcr.3.1.299.

\section{INTRODUCTION}

Women have always been oppressed, marginalized and subjugated in a male patriarchal society. Many African societies are grounded in patriarchal values that saw women as second class, and even at times "inferior" to men. Beliefs and practices that indicated this marginalization of women to the fringes and background of the society include: (1) the male child being valued more than the girl child, (2) the lack of formal education for the girl-child, (3) women not being allowed to speak in public gatherings, (4) discrimination against childless women, (5) maltreatment of widows, and so much more. The reality of the oppression and discrimination against women is corroborated by Finley (xxi), Igube (1-17), Akintan (2-4), OlaAluko (17), Mojekwu-Chikezie (viii), Akintunde (v-vi). It is true that in many and almost every African societies there has been great improvement in the treatment of women. The girl is now being valued as the male child more than ever before to a certain degree and the girl-child now has access to formal education. Women now speak in public more than ever before. There is an improvement in the treatment of widows and there is more empathy today for childless women. In spite of these little gains and improvements, African attitudes and practices towards women is still greatly informed by patriarchal foundations. Take for instance the issue of childless women that this paper is concerned with; childless women continue to suffer from social stigmatization and many other pains.

This paper is written from a moral philosophical or ethical perspective. It uses critical hermeneutics to interpret and analyse the place of children in African culture and the place of the childless woman in African cultural practice. The paper proceeds by offering a literature review, explication of concepts. Thereafter it will examine the child in African thought or culture. With this done, it will present the plights and pains of childless women in Africa. The paper will then do a moral or ethical critique of the situation of childless women. A concluding reflection will bring the paper to an end.

\section{LITERATURE REVIEW}

It will be nearly practically impossible to review every book that deals with childlessness and women issues. The focus will be on works that deal with the situation of childless women in African culture. Egede in 2015 discusses the stigmatization of involuntary childlessness women in Sub-Saharan Africa. She discusses various ways that women have suffered stigmatization and dehumanization. She discusses the issue from a legal-judicial perspective and advocates empowering women to have access to assisted reproductive technologies. She shows that such women face a lot of trauma, personal loss, tragedies and negative sociolinguistic words are used to describe them. Names that show that they are inferior, barren, and sterile are equally used to erroneously describe them. Her work does not discuss the issue from an ethical perspective explicitly in naming this maltreatment of women as immoral and unethical. Abasili in 2015 examines the problem of childlessness and "sonlessness" in Africa in comparison with the plight of Hannah in $1^{\text {st }}$ Samuel 1 in the bible. He shows that the childless woman is often abandoned, neglected and silenced in the background. In the light of the biblical passage, he calls for a just 
response in ameliorating their plights. This work is a contextualized bible reading of $1^{\text {st }}$ Samuel 1, the Hannah story in the light of African culture. Abasili in his 2011 work uses African cultural hermeneutics to examine Genesis 38 and from the story of Judah and Tamar unveils the tragedies and pains that women are subjected to in order to produce progeny and heir; and questions the male patriarchal society that tolerates this. He shows in his paper that just as the Hebrew people see sexual intercourse for procreation so also in Africa. Bolayi in 2019 examines the pains and challenges of infertility in "The Secret Lives of Baba Segi." Bolayi writes that the author of this novel, Lola Shoneyin reveals the pressures that women face in childless marriages in which they are blamed for infertility. Bolayi states that in the novel it is argued that:

(1) women's sexuality is viewed with a patriarchal prejudice; (2) the referral of infertile woman as worthless, which in essence reveals the quality of their inter-subjective relationship, depicts men as the agents and women as the objects in marriage; and (3) that the order of the African family unit is deeply constructed on gender lopsidedness. In the end, Masenya's notion of bosadi (womanhood) is employed to indicate the significance of the way in which a woman was created by God to be a fully active human. (par 1)

The work of Okpala and Utoh-Ezeajugh written in 2018 discuss the fact that the oppression, discrimination and other problems that women faces are both inter-gender and intra-gender, patriarchy is not the only source of women suffering, and using the theories of Focus of feminism, Snail Sense Feminism and Womanism they call for love and empathy among women. Another paper that discusses the issue related to this is Rouchou written in 2013. His work is on infertility in developing countries and the psychological, social and economic consequences. The work shows that this issue is a public health issue deserving attention to overcome the social stigma, economic security loss and negative psychological impact. It is Igbo birth songs as depicting the maternal and motherhood destiny of the woman that Okerenke examines in her 1994 piece. Sharma, Saxena, and Singh devote their own paper to historical and scientific perspectives on infertility and assisted reproductive methods.
They show that a stigma is attached to infertility and that childless women are subjected to social, mental, and physical damages. Oti-Boadi and Asante focus on how religion is a resource for infertile women to cope with the psychological effects of childlessness. Chidili in 2005 examines the implications of lack of offspring in marriage. He states the importance of human continuity is central to African thought and argues for an African privilege of allowing the woman to be taken to alleviate the challenge, allowing nullity for marriages that fails to produce a son or children.

\section{Explication of Concepts}

It is important to explicate some concepts that ground this paper. They are: unethical, abuse, childless women, African traditional thoughts/practice. Ethics also known as moral philosophy is a branch of philosophy that is concerned with studying issues of right and wrong. Fieser writes that ethics which is also called moral philosophy deals with defending, systematization and recommendation of what is right or wrong (par 1). It studies what makes a thing or behaviour right or wrong. And so, it studies the criteria or standard on which human behaviour is based. Ekweolo rightly states that: "Ethics is the systematic study of the fundamental principles of morality. As a study, it is a critical examination of values with the view to having a qualitative way of living and conduct. It examines the rights and wrongs in human conduct and the society" (1).

It is true that various societies have their own standard of measuring what is moral or evil. In spite of these through universal human rights instruments and universal consensus, there are things that humans have come to perceive as right or wrong. It is now generally understood that slavery, human trafficking, oppression, colonialism, racism, ethnicism, murder, arson, genocide, and much more offend against the value and dignity of the human person. There was a time in human history in which some of these were permitted. A long time ago slavery was permitted. Today it is no longer accepted. As human beings grow in knowledge and enlightenment, they move towards more positive values that bring better benefits to the human race. Various forms of oppression and maltreatment of women may have been accepted in the past in a 
male-dominated patriarchal culture, they are not accepted today. Maltreatment of childless women or women who suffer from involuntary infertility is unacceptable today and unethical because they offend against the dignity of women as human beings.

The term, childless women refer to women without biological children or who are unable to have children in life. It is often involuntary on their part and may be due to factors beyond their power. While in this paper, childless women are called infertile women yet the two terms are not synonymous. Infertility is a main cause of childlessness but not the only cause. In this work, the two terms, childless women and infertile women will be used interchangeably.

The work is concerned with the abuse of childless women. It is important then to equally define abuse. For The Gale Encyclopedia of Mental Health abuse refers to any harmful treatment or injury caused to others and it could be in the realm of the sexual, physical, psychological, verbal, emotional, and spiritual, or intellectual (par 1). Depriving others or denying them of their rights can amount to abuse. This work indicates that childless women in Africa because of their situation are subjected to verbal abuse, psychological torture, physical violence, economic deprivations, and other pains meted on them. The work categorically asserts that this maltreatment against childless women is unethical or immoral. The case of childlessness in women is involuntary and except in very rare exceptional cases. Because it is involuntary nobody should be punished or maltreated because of it. Rather what they deserve in the spirit of altruism and humanism is empathy, compassion, and solidarity.

Also deserving of explication is African traditional thought and practice. African traditional thought refers to the beliefs, ideas, customs, cosmologies, and worldviews of African people from time immemorial predating the adventure of Europeans into the African continent. African traditional practices imply all the behaviours, ways of life and response of Africans based on their traditional beliefs. Traditional here is what is indigenous to Africa coming from the African soil especially before the European advent. It is not imported into Africa. It is grounded in the African worldview.
African beliefs about the gods, divinities, ancestors, the earth, human persons, animals, plants, etc are part of African traditional thought. African traditional practices are a reflection of the beliefs and values of African people spanning generations (Labeodan 68). Today, though African traditional thought and even practice have been "contaminated" by western beliefs and cultural practices; it is still identifiable. African traditional thoughts and practices are part of African oral works of literature. The paper examines the attitude and response to childless women in African traditional thought/practice (culture). The goal here is to ethically critique the beliefs and practices towards childless women in African culture.

\section{The Place of Children in African Thought/Practice}

\begin{abstract}
African society is structured largely around the lives of its children. Across the continent, children represent continuity with rituals and contemporary institutions designed to ensure children's survival and prosperity. At the same time, children are viewed in many African cultures as crucial to family survival itself, in that they help maintain household economies through their cheap labor in the home, in family agricultural or food-processing activities, or in trade or artisanship (Children and Childhood).
\end{abstract}

Mbiti conveys the importance of childbearing in African marriages, stating: "Marriage and childbearing are the medicines against death. While death continues to demolish life, marriage and childbearing keep ahead of it all the time" (105). The cardinal reason for marriage in African traditional culture is the procreation of children. Kofon argues that: "In Bafut (and other parts of Africa) people marry because they want to have children. This is the principal aim. There is no marrying simply for personal fulfillment or for mutual pleasure of the spouses. Begetting children is a duty to be fulfilled" (52). Having many children is necessary for the prolongation of the tribe or community. Turaki says that the African man has to have children to continue the survival of his family (107). It is firmly believed that Children are gifts from God, the gods and ancestors. Gaskiyane elucidates: "In traditional cultures the greatest desire and requirement is to have children, 
especially male children, to be heirs of property" (15). In this context, Waruta and Kinoti further contend that "Not only is the birth of a child important amongst the African people, but the gender of the child is also important. Male children are valued, especially in many patrilineal African societies" (36). Shorter, "polygamy serves the prosperity and growth of the extended family and provides status and support for women in societies where they have no vocation other than marriage and the bearing of children to their husband's lineage." Egede corroborates these ideas in affirming that children are seen as reincarnations of the ancestors, they add procreational value to life and serves as the link between the unborn and the dead (51).

Mbiti in 1991 notes the following about children: the product of marriage is children; children seal the bond of marriage, children are signs of longevity for parents and perpetuate the family line, children bring glory and wealth (114-115). In Urhobo orature or tradition of the Niger Delta region of Nigeria, the names given to children reveal the value and place of children in the society. Names such as: Omonigho (child is bigger than wealth), Omowho (the child is a person), Emokiniovo (children are brothers), Emorurukpe (children of light), Emamoemo (good children), Emorirhe (children have come), etc. All these names indicate the value that is placed on children and their place in society.

Children, especially male children were also valued for their economic purposes. In traditional African societies, rural communities and in the hinterland in Africa, agriculture whether farming or fishing was the major source of income and sustenance of the family. Children were needed to enhance labour and productivity. Baloyi writing in 2013 assert that: "In most African cultures men (males) are generally assumed to be the breadwinners. Stock and crop farming were the common means of survival, and both require strength and labour" (171).

Without children, there will be no future for the family, ethnic group, community, etc. Children help in household chores, and in the neighbourhood and in the farmland and fishing activities. As the children become adolescents and young adults they apprenticed and learn various skills in the community.
It is children who become young persons and adults and takes over responsibilities from their aged parents. Life was supremely valued in Africa and it is expected that children will grow old, become aged, live long lives and die at old age. Dying as a child was seen as a curse. Children are not giving proper burial. They are hurriedly buried without any proper ceremony or rites. It is a bad omen shunned by every family and African people. The birth of children brings great joy to the African community, but any mishap in pregnancy or death of the child is intolerable and unacceptable. Prayers and various rituals are performed to ensure that the pregnant woman delivers safely. Mages writes that conception occasions joy, and healthy delivery and uncomplicated birth brings more joy and consolidates marital relationships (83).

The above value placed on children informs some of the attitudes towards childless women. It is to the abuse, plight and predicament that they face that this piece now turns.

\section{The Abuse, Plight and Predicament of the Childless Women}

Childless women are made to face a lot of abuses. When a woman is unable to have children, some African men turn to polygamy. The man is often pressured by his family members and even friends to take another wife. Polygamy has many negative effects on the childless woman. Many women in Africa also suffer from the negative effects of polygamy. Baloyi in 2013 cites Yamani to presents the following definition of polygamy: "From its Greek origin, the word polygamy is understood in the broader sense to include any simultaneous multiple marriage unions for one person, such as female polyandry and male polygyny" (165). The just mentioned author citing Yamani states that: "however, the word polygamy is used ...to describe the state of a man having more than one woman, including the religious, legal and customary aspects of these unions" (165). Polygamy is a form of marriage in which a man is married to more than one wife. One of the reasons for polygamy is childlessness. Because of the great value placed on children as necessary for the sustenance of the family and community, when in marriage there are no children some African men quickly take more women in order to give birth to children. In African 
traditional culture recognizes that infertility is a very good reason for a man to marry another wife. Polygamy suffers from a lot of pressure. There is competition in the family over economic resources that are often scarce. The childless woman is often verbally abused and called evil names by the man or the new woman (co-wife) of the in-laws. At times the bedroom is taken over by the new wife and the first or earlier wife is sent to the boy's quarter or other rooms outside the main house. The childless woman is humiliated and disgraced. Still on the negative effects of polygamy, Baloyi in 2013 quotes ideas from Struensee that: "Among the things that a critical evaluation of polygamy helps us to see is that not only does it encourage the treatment of women as inferior beings, but it also foments rivalry between wives and forces many women to share already scarce resources with co-wives and their children. It also has an impact on women's health, and has a detrimental effect on the many children that the polygamist will have" (175-176). Okorie in 1995 mentions the jealousy and intense envy that polygamy gives rise to among the wives" (6). Conflicts and quarrels are constant occurrences in polygamous homes. All these create stress, and can even make the childless women depressed.

A woman who has no children, especially male children is seen as diminishing the labour force and economic productivity. She is seen then as not contributing to the traditional economy. Egede puts it that the involuntarily childless woman faces a cosmological and existential question as she fails to contribute to the link between the dead, the unborn and the living and so she is not enhancing the Ubuntu (51).

According to Maillu in 1998, a woman can be expelled from the house and subjected to begin to search for another husband. The expulsion of a barren woman from the household can often be very traumatic and stressful. The woman can be forced to pack out of the husband's house. Catherine C Kitur writes of the Kipsigis Community in FortTernan Region, Kericho County that: "Childbearing is believed to be the primary role of a woman thus childless women are expelled from their matrimonial home for failing to contribute to the family." This is applicable to many indigenous cultures.
In the case of infertility or lack of ability to give birth to children the woman was the first and often is the person blamed for the situation. Even when it is obvious that the incapacity may be from the man, the man is exempted and the woman is claimed to be a carrier of bad luck. Baloyi writing again in 2013, has rightly stated that both men and women should undergo fertility tests before any form of marriage and the woman should not be automatically blamed for infertility. Abasili in 2015 writes that: "In such patriarchal contexts, it is the women who often bear the brunt of childlessness or "sonlessness" and are branded 'unfruitful.' As a result, they run the risk of either losing their marriage or sharing their husband in a polygamous family with a 'fruitful' co-wife." It should be understood that the plight of childless women is not limited to Africa. It exists in almost all so-called developing countries. Rouchou (2013) indicates that in Indian culture affluent women were accused of being more interested in their careers, poor women who are childless are called, "machi" (farm animals that cannot breed). Rouchou writing in 2013 states further:

Intrusive questioning is common in Indian culture. Women of all classes admitted to feeling insulted and embarrassed when confronted with queries about trying to conceive. It was found that poor women tended to feel shame and anxiety from these social interactions because they assume that society attributes their infertility issues to something, they did wrong. Although affluent, infertile Indian women are discredited by society, they are less likely to stigmatise themselves because they have an occupational identity and social support from other married couples who cannot conceive; therefore, it has been shown in India that social class mediates selfstigma.21 Common between the classes, however, is that a household without a child is deemed unfortunate and desolate by Indian society. This barrenness is considered to be a curse of the infertile woman, as blame is rarely put-on men. (p. 175)

What this paper calls linguistic/verbal violence is also done against the childless woman/wife. Using the Hannah story in the bible, Abasili in 2015 propounds that just as Penninah verbally abused, irritated and provoked Hannah by taunting her maliciously so childless women are treated in 
African culture. The other effect is that Hannah refuses to eat and stays in weeping, as Abasili notes. Abasili in 2015, cites Mary Evans stating: "since Peninnah had many children, including several sons, Hannah's childlessness was to Elkannah little more than a minor inconvenience, one easily overcome by mutual affection (v. 8). But to Hannah, it was a personal tragedy." Abasili in the paper just mentioned states further that: "This is because the most important duty of a married or betrothed woman in the Hebrew bible is the begetting of offspring for her husband otherwise she will be viewed as a disgrace. No wonder Rachel in her childlessness said to Jacob 'Give me children, or else I die' (Gen 30:1); a clear expression of her desperation and deep sorrow. Thus, childless women in the Hebrew bible do everything within their power to resolve their childlessness."

At times the pain meted out to women can also be meted out to men as they are stigmatized. Rouchou notes that in South Africa, men were pressured to have extramarital affairs; men were called "tjoekee" (failure), "incabi" (castrated cow), shooting banks, bad swimmers and are socially isolated. Egede writes that among the Yoruba the childless woman is called "agon" (to be despised), among the Igbo she is called, "Mgbaliga, Nwanyi-iga" (the sterile woman or sterile monster who has maternal organs for mere decoration woman), in Uganda, the word "Mgunba" (the one who is infertile) describes her, and in Tanzania, they use the term, "Tassa" (infertile chicken) (56). The amount of pain, emotional trauma and psychological torture that the childless women go through is unquantifiable and immeasurable. Because of the stigmatization of women and the pressure on them they are often driven to consult in darkness spiritualists and native doctors. Some women suffer abuses also at the hands of these spiritualists and native doctors. Some are raped and forced to succumb to various demands of these spiritualists.

\section{Ethical Evaluation of the Abuse of Childless Women in African Culture}

The preference for male children in African culture is unjust and denies females of their dignity and equal rights with males. It is a reality to be frontally critiqued. Abasili in his 2015 work rightly notes that this lop-sided preference amounts to discrimination; it is unacceptable and unfair.

As noted previously it will be wrong to relative ethics and morality. For the ethical relativist, Dzurgba (8) writes that morals are relative and vary from time to time and depend on cultures. Citing Andrew G Oldenquist, Dzurgba (8) states that ethical relativists believe that: "an action that is right in one place or society may be wrong in another place or society," "whatever a culture or society thinks is right, is right for that culture or society," "whatever a person thinks is right, is right for him," and "everyone ought to do what he thinks is right." The dangers of relativism are grievous for society. Imagine if it was accepted in Africa that means there will be no basis to condemn discrimination against women and the violations of their rights. It means that a society that stigmatizes childless women should be left like that as far as it is their belief. While it is true that there are peculiarities in every culture, whatever in a culture offends against the common good of the universal society should be condemned. If there are cultures that are isolationist today and island to themselves, they are very few. Cultures and societies in this time of globalization that have mingled and interacted with other cultures in the global society should insist that their cultures should be spared criticism. There are basic universal norms that guide nations, it is on this basis that slavery, colonialism, racism, and apartheid, etc are ethically condemnable. Human beings no matter where they live have inalienable rights and fundamental dignity. The United Nations states: "all human beings are born free and equal in dignity and rights" (art 1). And the UN Convention on the Elimination of All Forms of Discrimination against Women calls for an end to all discrimination against women. All children, men, and women are equal in dignity.

There is a need to create an ethics of care to enhance the dignity of women, especially childless women. The worth of a woman should not be seen merely as that of child-bearing. A woman is still valuable even when she is not a biological mother. Baloyi writing in 2001 notes that the purposes of marriage include partnership of life, intimacy, friendship, complementarity, and friendship. There is a need to create an ethics of care for childless women in Africa. Abasili rightly notes that "Patriarchalism 
should be replaced with marital justice and sexual fairness" (p.14). He notes that women should not be made powerless and speechless as happens to Tamar in Genesis 38. They should not be denied sexual justice and their rights to personhood should be guaranteed even when they have no children.

The issues raised by feminist's philosophy, ethics, and movement should not be ignored here. Feminist ethics like other forms of feminism have decried the oppression of women and children in a male patriarchal culture that often sees women for their sexual procreative functions. The rights and status of women even childless women need to be recovered. While there are extreme and radical forms of feminism that struggles against men and sees men as evil, true and authentic feminism strives for the fair and just treatment of both men and women. As Nnamani (153) notes radical feminist carries a separatist ideology as they attack the family, critique child-bearing which they claim make women weak, and even advocate childbearing without women carrying pregnancy. While this paper advocates for the negative dimensions of patriarchy to be dethroned it does not advocate for erosion of child-bearing and nurturing dimensions of women's lives. This is why it is important to mitigate feminism equally with the womanist philosophy. Womanist philosophy as Nwaneri (14) notes places emphasis on social harmony seeks protection of men and women and fosters motherhood. Nnamani (172-173) states that western feminism should be questioned and the feminine dimensions of women's lives should not be eroded. This paper agrees with Nnamani (175) that some western-style feminism that promotes separatism, abdication of womanhood, voluntary childless (in marriage), abortion on demand, freedom with no responsibility. Authentic feminism should work for the solidity and healthy treatment of childless women. It is equal treatment of men and women that the paper advocates for. Childless women are as valuable as women with children and should not be denied human rights and economic opportunities because they are infertile. Society should be in solidarity and compassion with them.

The philosophy of personalism and Kantian ethics should also be recalled here. The human person should be treated as a human person no matter the gender. Men and women share in the same basic human ontology. Women are not less human than men. Women should not be seen and treated as simply procreation objects whose cardinal function is child-bearing. Every child whether male or female is a human being. Despite the emphasis on male children, traditional culture also at times recognized that the female child is a human being and should be accepted. Names given to the girlchild in Urhobo culture reveals this: Omotejowho (girl is also a person), Emeterirhe (the girls have come), Oro (gold or golden),

There is a need for a new moral or ethical rearmament and conscientization in society, especially of children and youth. Many authors such as Nnamani (143) have shown that much of human culture and history socialization process made people believe that men are superior, while women are inferior, and to the extent that women are to live in subjugation. Aristotle as cited by Nnamani (144) taught that women are inferior and men are to rule over them, women are defamed in nature. The misogynism of Aristotle still pervades today. For much of the history of most world religions women have been seen as weak, inferior, and to be subjugated to men. The Old Testament and Paul's teachings have been used by some of the early church fathers and theologians to say that Eve, a symbol of all women brought about the fall, and they are good for only childbearing and they are to keep silent in churches. Education and the entire socialization process should rise up to the challenge of re-educating the human mind. The human mind needs to be liberated from these misogynist beliefs and practices. Women are not inferior to men. The girl-child is as valuable as the male child. Women should not be made to suffer for giving birth only to gild-children. Women without children should not be made to go through more torture and pain in a society in which they are already suffering because of patriarchal norms. This is why Ola-Aluko (20) citing Lasebikan argues for separating womanhood from motherhood. Even without motherhood women should be encouraged to exercise their creative abilities, ingenuity, gifts, etc, as Ola-Aluko (20) says. This paper affirms that motherhood should not be limited to biological-sexual motherhood. Women can play maternal roles of nurturing, care, mentoring, etc in society. Women can become mothers by adopting children. 


\section{Concluding Reflections}

The paper has examined the plight, predicaments, and abuses of childless women in African culture, and by implication oral literature. The paper revealed that childless women are verbally abused, physically beaten, psychologically abused and maltreated. The paper argued that it is unethical and immoral to maltreat childless women for involuntary infertility. It also revealed that in some cases the cause of infertility is from men. The entire purpose of marriage is not just for child-bearing. It is equally for partnership of life, sharing of resources, etc. Motherhood should not only be conceived in biological terms. Men and women are ontologically equal though they may play different roles in society. Informed by various human rights declarations, it is important to end the abuse of childless women.

\section{REFERENCES}

Abasili, A.I. "Hannah's ordeal of childlessness: Interpreting 1 Samuel 1 through the Prism of a childless African woman in a polygamous family." Old Testament Essays. 28 (3). 2015. Web.

http://www.scielo.org.za/scielo.php?script=sci_artt ext\&pid=S1010-99192015000300003Abasili, A.I. "Seeing Tamar through the Prism of An African Woman: A Contextual Reading of Genesis 38." Old Testament Essays, 24(3). 555- 573. 2011.http://scielo.org.za/pdf/ote/v2 4 n3/01.pdf

Akinta, Adeoti. "Women in Yoruba Culture." Women and the Culture of Violence in Traditional Africa. Ed. Dorcas Akintunde and Helen Labeodan. Ibadan: Sefer. 2002. 1-16.

Akintunde, Dorcas. "Preface." African Culture and the Quest for Women's Rights. Ed. Dorcas Olu Akintunde. Ibadan: Sefer.2000. v-vii.

Baloyi, G.T. "An African woman's dilemma in The Secret Lives of Baba Segi's Wives: A bosadi perspective on the challenges and pains of infertility," Verbum et Ecclesia, 40(1).2019. 10 November 2019. https://verbumetecclesia.org.z a/index.php/ve/article/view/1957/3831
Baloyi, M E. Counselling Christian Shangaans on choosing a marriage partner. MA dissertation: Potchefstroom.2001.

Baloyi, Elijah M.”Critical Reflections on Polygamy in the African Christian Context," Missionalia: South African Journal of Mssiology (Online) 41.2. (2013):164-180. 13 Nov 2019. http://www.scielo.org.za/scielo.php?script=sci_ arttext\&pid=S0256-95072013000800006

Chidili, Bartholomew Udealo. Provocative Essays on the Practices of Religion and Culture in African Society. Jos: Fab Anieh Nigeria Limited. "Children and Childhood". In obo in African Studies. 8 Nov. 2019.

<https://www.oxfordbibliographies.com/view/docu ment/obo-9780199846733/obo9780199846733-0045.xml>.

Dzurgba, Akpenpuun. Contemporary Ethics: Theory and Issues. Ibadan: John Archers (Publishers) Limited.

Egede, Hephzibah. The Social Stigmatisation of Involuntary Childless Women in Sub-Saharan Africa: The Gender Empowerment and Justice Case for Cheaper Access to

Assisted Reproductive Technologies? 2015. 10 November 2019. https://orca.cf.ac.uk/91231/1/ 2015egedehphd.pdf

Ekwealo, Chigbo Joseph. "Ethics and Morality: Introduction to Applied and Practical Ethics." Applied and Practical Ethics: A Simplified Course. Ed. Chigbo Joseph Ekwealo. Lagos: African Environmental Ethics and Values Research Group of Department of Philosophy, University of Lagos. 1-17.2012.

Fieser, James. "Ethics." The Internet Encyclopedia of Philosophy, ISSN 2161-0002. 9 November 2019. https://www.iep.utm.edu/ethics/Finley, Laura L. "Introduction." Encyclopedia of Domestic Violence and Abuse. Ed. Laura L Finley. Santa Barbara, California: ABC-CLIO. 2013.ix-xxxii.

Gale Encyclopedia of Mental Health. "Abuse." Encyclopedia.com. 9 Nov. 2019. <https://ww w.encyclopedia.com>. Gaskiyane, I. Polygamy: 
A Cultural and Biblical Perspective. London: Piquant.2000.

Igube, Restituta b. Women and Gender Studies. Abuja: Sir Kuf Ventures Nigeria Company. 2004. Kitur, Catherine C. "The Perceptions of Childlessness in Women among the Kipsigis

Community in FortTernan Region, Kericho County." Impact: Journal of Transformation1. 1. (2018). 10 November 2019. https://journals.aiu.ac.ke/index.php/impact/artic le/view/16

Kofon, N E. Polygyny in pre-Christian Bafut and new moral theological perspectives.Frankfurt: Peter Lang. 1992.

Labeodan, Helen. "Beyond Critique: A Philosophical Appraisal of Some Cultural Practices."Women and the Culture of Violence in Traditional Africa. Ed. Dorcas Akintunde and Helen Labeodan. Ibadan: Sefer. 2002. 68-78.

Magesa, Laurenti. African Religion: The Moral Traditions of Abundant Life. Nairobi: Pauline Publications. 1998.Maillu, D G. Our Kind of Polygamy. Nairobi: Heinemann. 1988.

Mbiti, John S. Introduction to African Religion. Nairobi: East African Educational Limited.1991.

Mojekwu-Chikezie, Nneamaka M. African Women: Sentenced by Tradition. Ikeja, Lagos: A.A. Nwokebi \& Company. Nnamani, Amuluche Greg. "Feminism and the Future of Nigeria." Human Rights in Nigeria:

The Way Forward. Ed. Callistus Onyebuchi Asogwa. Enugu: Praise House Publishers. 143179.Nwaneri, Benjamin. "Africana Womanism: The Nigerian Woman and Cross-Cultural Justification." The Feminist-Womanist Dialectics: A Critical Source Book, a Festschrift in Honour of Professor MRS Akachi AdimoraEzeigbo. Ed. Y.O.O Akorede and A.A. Asiyanbola. 13-32. Bedford, UK: Lyette Books. 2010.

Ola-Aluko, Yetunde. "Women, Culture and the African Society." Women and the Culture of Violence in Traditional Africa. Ed. Dorcas
Akintunde and Helen Labeodan. Ibadan: Sefer. 2002. 17-27.

Oderinde, Olatunde "Equal Rights Policies and the Multiple Roles of Women." Women and the Culture of Violence in Traditional Africa. Ed. Dorcas Akintunde and Helen Labeodan. Ibadan: Sefer. 2002. 28-40.

Okpala, Ebele Peace and Tracie Chima UtohEzeajugh. "Inter and Intra- Gender Discourse in African Prose: An Interrogation of the Female Image in Selected Literary Texts." UJAH, 19 (2). 1- 24. $2018 . \quad$ http://dx.doi./org/10.4314/ ujah.v19i2.1

Okereke, Grace Eche. "The Birth Song as a Medium for Communicating Woman's Maternal Destiny in the Traditional Community," Research in African Literatures, 25 (3) Women as Oral Artists (Autumn, 1994), pp. 19-32. https://www.jstor.org/stable/3819843?seq=1\#pa ge_scan_tab_contents

Oti-Boadi Mabel and Asante, Kwaku Oppong. "Psychological health and religious coping of Ghanaian women with infertility." Biopsychosoc Med. (2017) $11 \quad$ (20). Jul 12. DOI: $10.1186 / \mathrm{s} 13030-017-0105-9$

Rouchou, Britanny. "Consequences of infertility in developing countries," Perspectives in Public Health. 2013. 10 November 2019. http://citeseerx.ist.psu.edu/viewdoc/download?d oi=10.1.1.817.8982\&rep=rep1\&type $=$ pdf

Sharma, Radhey Shyam, Saxena, Richa and Singh,Rajeev. "Infertility \& assisted reproduction: A historical \& modern scientific perspective." Indian J Med Res. 2018 Dec. 148(Suppl 1): S10-S14. 10 November 2019. doi: 10.4103/ijmr.IJMR_636_18

Turaki, Y. 1999. "Christianity and African Gods: A Method in Theology." Wetenskaplike bydraes. Series F2 no. 75. Potchefstroom University for Christian Higher Education. United Nations. "Convention on the Elimination of All Forms of Discrimination against 
East African Journal of Traditions, Culture and Religion, Volume 3, Issue 1, 2021

Article DOI: https://doi.org/10.37284/eajtcr.3.1.299

Women.” 18 December 1979. 10 October 2019. http://www.ohchr.org/documents/professionalin terest/cedaw.pdf.

United Nations. "Universal Declaration of Human Rights." December 10, 1948. 4 October 2019. http://www.un.org/en/universal-declarationhuman-rights/index.html

Waruta, D W \& Kinoti, H W. Pastoral Care in African Christianity. Nairobi: Acton. 2000. 